\title{
Serum Selenium Levels and Nutritional Status of School Children from an HIV Prevention Programme in Zimbabwe
}

Patience Kuona $^{1^{\star}}$, Grace Mashavave ${ }^{2}$, Gwendoline $Q$ Kandawasvika ${ }^{1}$, Janet Dzangare ${ }^{3},{\text { Mufarowashe } \text { Masanganise }^{4}, \text { Precious } \text { Chandiwana }}^{4}$, Marshall Munjoma $^{5}$, Kusum Nathoo ${ }^{1}$ and Babill Stray-Pedersen ${ }^{6}$

${ }^{1}$ Department of Pediatrics and Child health, University of Zimbabwe, Zimbabwe

${ }^{2}$ Department of Chemical Pathology, University of Zimbabwe, Zimbabwe

${ }^{3}$ AIDS and TB Unit, Ministry of Health and Child Care, Zimbabwe, Zimbabwe

${ }^{4}$ Letten Foundation Research Centre, Zimbabwe, Zimbabwe

${ }^{5}$ Department of Obstetrics and Gynaecology, University of Zimbabwe, Zimbabwe

${ }^{6}$ Division of Women and Children, Rikshospitalet, Oslo University Hospital and Institute of Clinical Medicine, University of Oslo, Norway

*Corresponding author: Patience Kuona, Department of Paediatrics and Child health, University of Zimbabwe, Zimbabwe, Tel: 263772396029; E-mail: patiekuona@gmail.com

Received: Feb 27, 2014; Accepted: Apr 11, 2014; Published: Apr 14, 2014

Copyright: (c) 2014 Patience Kuona, et al. This is an open-access article distributed under the terms of the Creative Commons Attribution License, which permits unrestricted use, distribution, and reproduction in any medium, provided the original author and source are credited.

\begin{abstract}
Nutrition programmes in resource poor settings mainly focus on children under the age of five years and this has resulted in limited information on nutritional and micronutrient status of school children in areas with high burden of HIV infection. This cross-sectional study assessed the prevalence of, and factors associated with stunting, thinness, overweight, underweight and selenium deficiency in school aged children from a high HIV burden peri-urban area in Zimbabwe, a low income country. Seven to 10 year old children from a prevention of mother-to-child transmission of HIV cohort had their serum selenium levels determined by mass spectrometry in a cross-sectional study. Height, weight, mid-upper-arm and head circumferences were measured to determine the prevalence of stunting, thinness, underweight and wasting. WHO growth standards were used to define the children's nutritional status.

A total of 318 children including $21(7 \%)$ HIV infected were assessed. The prevalence of stunting, thinness and underweight was $12 \%, 4 \%$ and $8 \%$ respectively. The prevalence of Selenium deficiency (serum Selenium $<0.89$ $\mu \mathrm{mol} / \mathrm{L}$ ) was $48 \%$ and it was found to be high in all the children despite their HIV status. Stunting was associated with HIV infection and orphan hood. There was no difference in height or weight between the HIV uninfected (exposed and unexposed) children who were in comparison both taller and heavier than the HIV infected children. Chronic malnutrition and selenium deficiency were prevalent in this cohort of children. Further studies are recommended to guide the need for selenium supplementation. Setting up health programmes to identify malnutrition in school aged children should be a priority.
\end{abstract}

Keywords: Selenium; School children; HIV; Stunting; Thinness; Underweight; Wasting; MUAC

\section{Introduction}

Malnutrition defined as under-nutrition in this article is a global public health problem underlying many childhood deaths [1]. Although global underweight figures have been showing declining trends in children under 5 years, underweight rates continue to rise in Africa. The number of underweight children is estimated to increase from 24 million to 43 million by 2015 in Sub-Saharan Africa [2]. In Zimbabwe, malnutrition is also a major problem exacerbated by the declining economy and the HIV/AIDS epidemic [3]. National statistics for under five children show that $32 \%$ are stunted, $3 \%$ are wasted and $10 \%$ are underweight according to the Zimbabwe demographic health survey 2010/2011 [4]. These figures have remained unacceptably high in the past two decades. Notably, nutrition programmes in resource limited settings have been focusing mainly on under-five children consequently resulting in a gap of knowledge on the burden of malnutrition and information on micronutrient deficiencies among the school-aged children particularly those from areas with a high burden of HIV infection.
Stunting and wasting remain important problems in school children [5,6] and high stunting rates in this age group have been reported in some areas in Africa [7]. Other developing countries are reporting a paradoxical existence of over-nutrition and undernutrition in school children [8]. Under nutrition in school children affects their growth, development, capacity to work and their cognitive function. Improving school children's nutritional status may improve their cognitive function and linear growth [9].

Malnutrition is a syndrome caused by various factors which include: reduced food intake, inadequate health services, poor maternal or child care services leading to nutrient deficiency and increased infections [10]. Malnutrition generally leads to delayed motor development, cognitive impairment, behavioural problems, social development deficiency, immunodeficiency, increased morbidity and mortality $[11,12]$. The hallmark of malnutrition is growth failure. Malnutrition can be acute or chronic. Body-massindex-for-age (thinness) is the indicator recommended by the World Health Organization to identify acute malnutrition (defined as a Zscore below -2) in children above 5 years. A height-for-age Z-score below -2 is used to define chronic malnutrition or stunting. Weightfor-age Z-score below -2 indicates underweight and is a composite 
representation of both wasting (thinness) and stunting [13]. Midupper arm circumference indicates wasting while head circumference is a proxy for brain growth.

Malnutrition is associated with micronutrient deficiencies [14,15]. Research has shown that supplementation to correct common micronutrient deficiencies such as iron, Vitamin A, Zinc or iodine deficiency is beneficial to children [16-18]. Hence, identification and treatment of micronutrient deficiencies is important. There are less common micronutrient deficiencies that are associated with malnutrition that have not been clearly defined in school aged children from resource poor settings such as selenium deficiency. Selenium is an essential element for human health [16], but there is limited research in Africa on the selenium status of children. It has an essential role in all aspects of the immune system [19] and is a necessary component of selenoproteins which are important for enzyme function in the human body [20]. Selenium is an antioxidant that protects the cell membrane and deoxyribonucleic acid $[21,22]$. This essential biological role of selenium protects the body from several diseases such as viral infections, cardiac disease, diabetes and arthritis [23-26]. Selenium deficiency increases mortality in HIV infected adults and children $[27,28]$. Therefore, it is necessary to determine the selenium levels in children from settings with high burden of HIV infection and malnutrition as this would help to guide the need for supplementation of this micronutrient. This article presents findings from a study that assessed the prevalence of, and factors associated with stunting, thinness, overweight, underweight and selenium deficiencyin school children whose mothers were recruited in a PMTCT programme in an area with a high prevalence of HIV infection.

\section{Materials and Methods}

\section{Study design}

This cross-sectional study was carried out from August 2011 to June 2012 at 3 peri-urban primary care clinics (Epworth, St Mary's and Seke North Clinics) in Zimbabwe. The participants were 7-10 years old school aged children whose mothers had been recruited into a PMTCT programme from 2002 to 2004. This was a sub-study in the Better Health for African Mothers and Children (BHAMAC) study which investigated the role of sexually transmitted diseases on vertical transmission of HIV and is described elsewhere [29]. Briefly, the BHAMAC study recruited women 36 weeks pregnant coming through the national PMTCT programme who underwent voluntary counseling and HIV testing. Hence the cohort of children comprised of HIV negative unexposed, HIV negative exposed and HIV infected children. HIV negative unexposed children are HIV uninfected children who were born to HIV negative women. HIV negative exposed children were born to HIV positive women but are HIV uninfected. HIV infected children were born to HIV infected women and became infected. All children between 7 and 10 years who were still alive from the BHAMAC cohort at the time of the study, whose care givers consented to be included in the study, were eligible for recruitment. The second siblings to the original cohort of children were excluded. The prevalence of malnutrition $(p)$ in this group of children was unknown and estimated to be $50 \%$. The minimum sample size required for estimating the prevalence of malnutrition (stunting, thinness or underweight) in this population of children with a confidence interval of $95 \%$ (significance level; $\mathrm{z}$ ) and a margin of error (se) of 0.05 was calculated to be 208 using the Raosoft ${ }^{\bullet}$ sample size calculator. The calculator is based on the following formula:

$$
\mathrm{n}=\mathrm{z}^{2}(\mathrm{p}(1-\mathrm{p}))
$$

$(\mathrm{se})^{2}$

During the planning stage of the study 452 children were still alive from the original BHAMAC cohort. A decision to include more than the 208 children was made so as to enable the assessment of selenium status of the children which was unknown for the Zimbabwean population. Caregivers in the community were contacted by peer counselors and were informed about the study. Participants were consecutively recruited as they presented to the local clinic every Thursday between 8 am and $6 \mathrm{pm}$.

\section{Data collection}

A data collection tool was piloted and then administered to collect socio-demographic data. All the children had a physical examination performed by a pediatrician. Height, weight, occipital-frontal (head) circumference and mid-upper arm circumference (MUAC) were measured. The children's weight was measured while they put on light clothing with a Seca digital scale (manufactured in Germany model: 881 1021659) which was standardized daily. A stadiometer was used to measure height. The children took off their shoes, stood feet together with the heels against the wall and looked straight ahead. One person would ensure the correct head position and another person ensured that the knees were extended while the heels touched the back of the wall. The head circumference was measured with a non-stretchable tape measure in the occipital-frontal diameter. The measurement was repeated 3 times and the largest measurement was taken as the head circumference. The MUAC was also measured in the non-dominant arm. The midpoint between the shoulder and the elbow was determined with flexible non-stretchable tape. The MUAC was then measured with the limb hanging down and relaxed. The WHO's Anthroplus (version1.0.4) was used to calculate Z scores for body mass index, weight for age and height for age. The WHO recommended Z score cut-offs for underweight, stunting and thinness were used to define under-nutrition. $\mathrm{Z}$ scores below -2 and -3 were considered as moderate and severe under-nutrition respectively. Children with a BMI Z-score below -3 for age were classified as severe acute malnutrition. They were managed according to the Ministry of Health protocol for managing severe acute malnutrition in children above 5 years with a ready to use therapeutic food (Immunut) [30]. The children were discharged from follow up once their BMI Z-score was above -2 or after 4 months in the program. Those who did not improve were referred to the district hospital for further investigation and treatment.

\section{Blood samples collection}

The skin was wiped with a methylated spirit-soaked swab and allowed to air-dry for one minute. A tourniquet was applied above the elbow joint and using appropriate protective equipment, blood was collected by venipuncture into a royal blue trace element tube. Care was taken not to haemolyze the samples. The specimens were immediately stored in a cooler box at a temperature between 2 and $8^{\circ} \mathrm{C}$ for transportation to the laboratory where they were spun for 10 minutes at 1100 revolutions per minute. At least two $1 \mathrm{ml}$ aliquots of serum were stored at $-80^{\circ} \mathrm{C}$ and one aliquot was shipped on blue ice to Fürst Medical laboratory in Norway for selenium determination. 
Page 3 of 7

\section{Serum Selenium determination}

Automated inductively coupled plasma mass spectrometry was used to measure serum selenium levels. A PerkinElmer Sciex; Elan ${ }^{\bigotimes}$ DRC ${ }^{\prime \prime}$ II (Manufactured 2005 Shelton, USA) spectrometer was used. The mass spectrometer generated single charge ions from elements in the sample. The ions were then separated based on mass-to-charge ratio and then detected. Internal and external calibrators were used for quality control as recommended by the manufacturer. There is no clearly set definition for selenium deficiency in this age group of children. However, in this study selenium deficiency was defined as a value below $0.89 \mu \mathrm{mol} /$ litre and this was based on studies from Vietnam [31] and Ethiopia [32] in children of a similar age group. These studies' definition was used to enable comparison of results since there is limited studies of selenium deficiency in children and selenium levels above this cut off are associated with favorable health outcomes [33].

\section{Ethics statement}

This study was approved by the Medical Research Council of Zimbabwe and the Norwegian Research Ethics Committee. After the study was explained to the participants, the care givers gave written informed consent and the children gave written assent to be included in the study.

\section{Statistical analyses}

The SPSS statistical package [IBM SPSS Statistics version 20.0.0.1] was used for statistical analysis. A p-value less than 0.05 were considered statistically significant. Descriptive statistics and prevalence calculations were used to describe the data. Correlation was used to describe continuous data. Chi square and fisher's exact tests were performed to determine associations between categorical data. The one-way Anova test and the Boniferroni Post-Hoc Test were used to compare means of continuous outcome variables according to the HIV status of the children.

\section{Results}

A total of 318 out of 452 children were recruited into the study. The excluded children were either no longer living in the area because they were displaced by a government programme that destroyed illegal houses in the area or their care givers did not wish to participate in the research. For $71 \%$ of the children, the primary caregiver was the mother and $19 \%$ were being looked after by their grandmothers. Only $4 \%$ of the primary care givers had not gone to school while $64 \%$ had gone up to secondary school. Most of the working mothers (93\%) were informally employed as vendors (38\%). Fifty seven per cent of the mothers were married, 9\% had remarried and 9\% were divorced. Seventy five percent of the children's fathers were alive and $52 \%$ of the children were living with their fathers in the same household. Table 1 shows the demographic features of the children.

\begin{tabular}{|l|l|l|}
\hline Characteristic & & Frequency \\
\hline Gender & & \\
\hline Male & Male & $137(43 \%)$ \\
\hline Female & Female & $181(57 \%)$ \\
\hline HIV status & Negative unexposed & $180(57 \%)$ \\
\hline
\end{tabular}

\begin{tabular}{|c|c|c|}
\hline & Negative exposed & $116(36 \%)$ \\
\hline & Positive & $21(7)$ \\
\hline & Unknown & $1(0.3 \%)$ \\
\hline \multirow[t]{3}{*}{ Orphan hood } & Double orphan & $15(5 \%)$ \\
\hline & Single orphan & $79(25 \%)$ \\
\hline & Not orphaned & $224(70 \%)$ \\
\hline \multirow[t]{5}{*}{ Primary Caregiver } & $N=318$ & \\
\hline & Mother & $226(71 \%)$ \\
\hline & Grandmother & $59(19 \%)$ \\
\hline & Sibling & $5(5 \%)$ \\
\hline & Other & $28(9 \%)$ \\
\hline \multirow[t]{6}{*}{$\begin{array}{l}\text { Primary } \\
\text { Education }\end{array}$} & & \\
\hline & No School & $11(4 \%)$ \\
\hline & Primary level ( $\leq 7$ years) & $93(29 \%)$ \\
\hline & $\begin{array}{l}\text { Secondary Level ( 8-13 } \\
\text { years) }\end{array}$ & $205(64 \%)$ \\
\hline & Diploma or Degree & $7(2 \%)$ \\
\hline & Unknown & $2(1 \%)$ \\
\hline \multirow[t]{3}{*}{ Mother's Occupation } & $N=285$ & \\
\hline & Formal & $20(7 \%)$ \\
\hline & Informal & $265(93 \%)$ \\
\hline \multicolumn{3}{|l|}{ Household } \\
\hline $\begin{array}{l}\text { Monthly income US\$ } \\
\text { median(Q1;Q3) }\end{array}$ & $N=268$ & $150(80 ; 250)$ \\
\hline $\begin{array}{l}\text { Total number of people } \\
\text { median }(\mathrm{Q} 1 ; \mathrm{Q} 3)\end{array}$ & $N=318$ & $5(4 ; 6)$ \\
\hline $\begin{array}{l}\text { Number children below } \\
10 \text { years median } \\
(\mathrm{Q} 1 ; \mathrm{Q} 3)\end{array}$ & $N=316$ & $2(1 ; 3)$ \\
\hline
\end{tabular}

Table 1: The demographic characteristics of 318 Zimbabwean school children aged 7-10 years

Table 2 presents results of the continuous variables measured in the children. There were six children whose head circumference and midupper arm circumference values were missing. Only 269 out of 318 children had their serum selenium values determined because trace element tubes had expired before the study was completed.

\begin{tabular}{|l|l|l|l|l|l|}
\hline Characteristic & $\begin{array}{l}\text { Frequenc } \\
\text { y N }\end{array}$ & $\begin{array}{l}\text { Mea } \\
\mathrm{n}\end{array}$ & $\mathrm{SD}^{*}$ & $\begin{array}{l}\text { Minimu } \\
\mathrm{m}\end{array}$ & $\begin{array}{l}\text { Maximu } \\
\mathrm{m}\end{array}$ \\
\hline Height cm & 318 & 127 & 6.9 & 104 & 149 \\
\hline Weight kg & 318 & 25 & 3.8 & 15 & 42 \\
\hline $\begin{array}{l}\text { Head Circumference } \\
\mathrm{cm}\end{array}$ & 312 & 52 & 1.6 & 47 & 57 \\
\hline
\end{tabular}


Citation: Kuona P, Mashavave G, Kandawasvika GQ, Dzangare J, Masanganise M, et al. (2014) Serum Selenium Levels and Nutritional Status of School Children from an HIV Prevention Programme in Zimbabwe. J Trop Dis 2: 134. doi:10.4172/2329-891X.1000134

Page 4 of 7

\begin{tabular}{|l|l|l|l|l|l|}
\hline $\begin{array}{l}\text { Mid-upper arm } \\
\text { circumference mm }\end{array}$ & 312 & 180 & 15.6 & 120 & 230 \\
\hline $\begin{array}{l}\text { Weight-for-age Z } \\
\text { score }\end{array}$ & 317 & $\begin{array}{l}-0.7 \\
7\end{array}$ & 0.93 & -4.97 & 1.72 \\
\hline Height-for-age Z score & 318 & $\begin{array}{l}-0.8 \\
8\end{array}$ & 1.03 & -4.96 & 1.96 \\
\hline BMI-for-age Z score & 318 & $\begin{array}{l}-0.3 \\
8\end{array}$ & 0.88 & -3.32 & 1.76 \\
\hline $\begin{array}{l}\text { Serum Selenium value } \\
\mu \text { mol/L }\end{array}$ & 269 & 0.85 & 0.16 & 0.30 & 1.60 \\
\hline
\end{tabular}

Table 2: The mean values of the anthropometric measurements and serum selenium of the school children from Zimbabwe

\section{*Standard Deviation}

Table 3 summarizes the prevalence of malnutrition and selenium deficiency in the children. Three children met the WHO criteria for community management of acute severe malnutrition with a ready-touse therapeutic food. Only one HIV uninfected child failed to recover after 4 months of treatment for acute severe malnutrition and required referral for further management at the provincial hospital.

\begin{tabular}{|l|l|l|}
\hline Characteristic & Indicator & Frequency $\mathrm{n}(\%)$ \\
\hline Stunting & Height-for-age $Z$ score $<-2$ & $37(12)$ \\
\hline & Height-for-age $Z$ score $<-3$ & $7(2)$ \\
\hline Underweight & Weight-for-age $Z$ score $<-2$ & $25(8) 1$ \\
\hline & Weight-for-age $Z$ score $<-3$ & $4(1)$ \\
\hline Thinness & BMI-for-age $Z$ score $<-2$ & $11(4)$ \\
\hline & BMI-for-age $Z$ score $<-3$ & $3(1)$ \\
\hline Overweight & BMI-for-age $Z$ Score $\geq 1$ and $<2$ & $15(5)$ \\
\hline Selenium deficiency & Serum Selenium $<0.89 \mu \mathrm{mol} / \mathrm{L}$ & $129(48) 2$ \\
\hline
\end{tabular}

Table 3: Prevalence of stunting, underweight, thinness, overweight and selenium deficiency among school children from Zimbabwe

$$
{ }^{1} \mathrm{~N}=317 \text { children }
$$

${ }^{2} \mathrm{~N}=269$ children

Children from households with a monthly income of less than US \$250.00 and from one site: Epworth clinic had a higher prevalence of selenium deficiency as shown in Table 4. There were no obese children. None of the overweight children was stunted. Two of the stunted children also had thinness. Of the 37 stunted children, 16 (43\%) were also underweight for age. HIV uninfected unexposed children were $7.5 \mathrm{~cm}$ taller than HIV infected children ( $\mathrm{p}=0.00)$. HIV uninfected exposed children were $5.4 \mathrm{~cm}$ taller than the HIV infected children $(\mathrm{p}=0.00)$. There was no significant difference in mean weight of the HIV uninfected (unexposed and exposed) children. However, HIV uninfected unexposed children were $3.5 \mathrm{~kg}$ heavier than the HIV infected children $(\mathrm{p}=0.00)$ and the HIV uninfected exposed children were $2.7 \mathrm{~kg}$ heavier than the children with HIV infection $(\mathrm{p}=0.01)$. There was no difference in head circumference among all three groups of children. HIV uninfected unexposed and HIV uninfected exposed children had MUAC size longer than that of children with HIV

infection by $11 \mathrm{~mm}(\mathrm{p}=0.01)$ respectively. There was no statistically significant difference in selenium levels among the three groups.

\begin{tabular}{|c|c|c|c|c|c|c|}
\hline Characteristic & $\begin{array}{l}\text { Freque } \\
\text { ncy }\end{array}$ & \begin{tabular}{|l} 
Stunti \\
ng
\end{tabular} & $\begin{array}{l}\text { Thinne } \\
\text { ss }\end{array}$ & $\begin{array}{l}\text { Overwei } \\
\text { ght }\end{array}$ & $\begin{array}{l}\text { Underwei } \\
\text { ght }\end{array}$ & $\begin{array}{l}\text { Sedeficie } \\
\text { ncy }\end{array}$ \\
\hline \multirow[t]{2}{*}{ Total } & 318 & 318 & 318 & 318 & 317 & 269 \\
\hline & & $n(\%)$ & $n(\%)$ & $n(\%)$ & $n(\%)$ & $n(\%)$ \\
\hline \multicolumn{7}{|l|}{ Gender } \\
\hline Male & 137 & \begin{tabular}{|l}
19 \\
$(14)$
\end{tabular} & $5(4)$ & $8(6)$ & $12(9)$ & $54(45)$ \\
\hline Female & 181 & $\begin{array}{l}18 \\
(10)\end{array}$ & $6(3)$ & $7(4)$ & $13(7)$ & $75(50)$ \\
\hline \multicolumn{7}{|l|}{ Age } \\
\hline 7 years & 21 & $5(24)$ & $2(10)$ & 0 & $1(5)$ & $8(38)$ \\
\hline 8 years & 105 & \begin{tabular}{|l|}
12 \\
$(11)$
\end{tabular} & $4(4)$ & $4(4)$ & $9(9)$ & $48(53)$ \\
\hline $9-10$ years & 192 & \begin{tabular}{|l}
20 \\
$(10)$
\end{tabular} & $5(3)$ & $11(6)$ & $15(8)$ & $73(46)$ \\
\hline \multicolumn{7}{|l|}{ Clinic } \\
\hline Epworth & 104 & \begin{tabular}{|l}
14 \\
$(13)$
\end{tabular} & $3(3)$ & $7(7)$ & $9(9)$ & $45(62)$ * \\
\hline St Mary's & 104 & $\begin{array}{l}12 \\
(12)\end{array}$ & $4(4)$ & $3(3)$ & $11(11)$ & $40(41)$ \\
\hline Seke North & 110 & \begin{tabular}{|l|}
11 \\
$(10)$
\end{tabular} & $4(4)$ & $5(5)$ & $5(5)$ & $44(45)$ \\
\hline \multicolumn{7}{|l|}{$\begin{array}{l}\text { Household } \\
\text { monthly income }\end{array}$} \\
\hline$\leq \$ 250$ & 205 & \begin{tabular}{|l|}
26 \\
$(13)$
\end{tabular} & $8(4)$ & $12(6)$ & $3(5)$ & $96(54)^{*}$ \\
\hline$>\$ 250$ & 63 & $6(10)$ & $1(2)$ & $1(2)$ & $20(10)$ & $15(33)$ \\
\hline \multicolumn{7}{|l|}{ HIV status } \\
\hline $\begin{array}{l}\text { NegativeUnexp } \\
\text { osed }\end{array}$ & 180 & \begin{tabular}{|l|}
12 \\
$(7)^{\star \star}$
\end{tabular} & $5(3)$ & $10(6)$ & $15(8)$ & $63(43)$ \\
\hline $\begin{array}{l}\text { Negative } \\
\text { Exposed }\end{array}$ & 116 & \begin{tabular}{|l|}
17 \\
$(15)$
\end{tabular} & $4(3)$ & $5(4)$ & $8(7)$ & $53(52)$ \\
\hline Positive & 21 & $8(38)$ & $2(10)$ & 0 & $2(10)$ & $13(62)$ \\
\hline \multicolumn{7}{|l|}{ Orphan hood } \\
\hline Not orphaned & 224 & \begin{tabular}{|l}
20 \\
$(9)^{*}$
\end{tabular} & $6(3)$ & $14(6)$ & $18(8)$ & $97(50)$ \\
\hline Orphaned & 94 & \begin{tabular}{|l|}
17 \\
$(18)$
\end{tabular} & $5(5)$ & $1(1)$ & $7(7)$ & $32(42)$ \\
\hline
\end{tabular}

Table 4: Factors associated with stunting, thinness, overweight, underweight and selenium deficiency in the school-aged children from Zimbabwe

\section{${ }^{*} \mathrm{P}$ value $<0.05$}

${ }^{* *} \mathrm{P}$ value $<0.001$ 

Test

Analysis done with One-way ANOVA and Boniferroni Post Hoc

\section{Discussion}

This is the first study to assess children's selenium status in Zimbabwe. This study demonstrated a high prevalence of selenium deficiency in children from an area with a high burden of HIV infection. It also showed mild prevalence of stunting representing chronic malnutrition in school-aged children from a PMTCT cohort. While no obese children were detected $5 \%$ were overweight. A quarter of the children were orphaned. Stunting was associated with HIV infection and orphan hood. Selenium deficiency was more prevalent in children from households with a monthly income below US\$250.00.

The prevalence of stunting of $12 \%$ in this study is of mild public health significance. This result is similar to findings from Burkina Faso which found prevalence of stunting of $8.8 \%$ in a similar peri-urban and urban setting. However, the children who participated in that study included older children of up to 14 years and their HIV infection status was not determined. It is lower than the prevalence of stunting from Tanzania, another sub-Saharan African country, which reported stunting rates of $52.5 \%$ [34]. It is also lower compared to results from studies from Asia [35-37]. Most of these studies included children above 5 years up to 18 years and were slightly older than the children who participated in our study. The exception was a study from Vietnam [31] with an almost identical age group (6-9 years) but slightly less number $(n=292)$ of children whose HIV infection status was unknown which reported quite a high figure of stunting of $33 \%$. This particular study also found gender differences in prevalence of stunting and underweight which was not demonstrated in our study. However, when stunting was stratified by HIV status, the prevalence of stunting was quite high in HIV infected children (38\%) in our study. This finding is similar toa research from Malaysia [37] in HIV infected children (21\%), but this particular study included children up to 18 years and had a much higher prevalence of severe stunting. In addition, orphaned children were more stunted in our study and this could be explained by the difficult socio-economic status that these children often endure. The prevalence of underweight $(8 \%)$ was much lower than that reported in Vietnam [31] and South East Asia [36] but similar to findings from Malaysia [37] in HIV infected children. The overall prevalence of thinness (4\%) was also much lower compared to an Africa study from Burkina Faso [38] but was similar to findings from Italy [39] a developed country. The prevalence of overweight was comparable to findings from Burkina Faso [38] and South east Asia [40] which are also developing nations. It was much lower compared to the developed countries in children of a similar age group [39,41,42] and it was also lower than findings from Malaysia [37] in HIV infected children on antiretroviral therapy. Some children had more than one nutritional deficit and this has been shown to increase risk of mortality in younger children [43]. The HIV uninfected (unexposed and exposed) children above 5 years had better nutritional status than the HIV infected children. Prevalence of stunting has been shown to be high in HIV infected children on and off antiretroviral treatment $[44,45]$. Prevalence of underweight and stunting have been reported to be higher among HIV infected children compared to HIV negative children [46,47]. Though the HIV uninfected exposed group of children were slightly shorter than the unexposed children this was not statistically significant. Their weight was also comparable. This finding from our study is in contrast to what has been described for younger children where HIV uninfected exposed children have been shown to have a high prevalence of malnutrition $[48,49$ ] compared to HIV uninfected unexposed children. The head circumferences of the three groups of children were not different.

Generally, the prevalence of selenium deficiency (48\%) was high in all the children despite their HIV infection status and this could be reflecting the selenium soil status of the region. The prevalence of selenium deficiency was comparable to results from Ethiopia (62\%) [32] and Vietnam (76\%) [31]. These two studies had almost similar sample sizes, used a similar cut-off value to define selenium deficiency, had similar mean selenium levels but the HIV status of the children were not determined. The prevalence of selenium deficiency in our study was much higher than that obtained in HIV infected children on antiretroviral treatment from Malaysia (12.5\%) [37] who also had a higher mean selenium level $(1.13 \mu \mathrm{mol} / \mathrm{L})$ and this study had a smaller sample size. There was no gender difference in the levels of selenium in our study and this was in contrast to results from Iran [50] which showed that girls had higher serum selenium levels. In our study selenium deficiency occurred more in children from households with a monthly income of less than USD $\$ 250$ and from children from one site which had a different geography from the other two sites. There was a tendency for selenium deficiency to be higher in the HIV infected children but this did not reach statistical significance. Though some studies have shown lower selenium levels in HIV infected individuals [51], there was no difference among the three groups in our study and this is similar to results found in Rwandan children younger than 5 years [52].It is important to note that selenium levels in different regions are influenced by the soil content of the element [53-55]. Some regions are well known for low selenium content for example areas in China [56] and Malawi [54]. The major limitation in our study was the much smaller sample size of HIV infected children. This study investigated serum selenium levels which reflect short term selenium status instead of red cell selenium levels which reflect long term selenium status [57]. We also did not assess the diet of the children which would have assisted in answering the question on why selenium and nutritional status was poor in this group of children. In addition, the assessment of nutritional status of the children was done only once; hence the study design did not address what was causing the malnutrition in the children.

Chronic malnutrition and selenium deficiency were prevalent in this cohort of children above 5 years who were born in a national mother-to-child prevention of HIV transmission programme. Health programmes to detect malnutrition are needed in this setting with a high burden of HIV infection for children above 5 years. Further and larger studies that will include children from rural and urban areas are recommended so as ascertaining the selenium status of this population. This may guide on the need for supplementation of selenium in this setting.

\section{Acknowledgement}

We are grateful to the children and their care-givers who participated in this work. The study was funded by the Letten foundation. We thank the UZ-UCSF laboratory (University of Zimbabwe), Fürst Medical laboratory (Norway), and the Department of Paediatrics and Child Health (University of Zimbabwe) for the assistance they gave us during the study.

\section{Conflict of interest}

All authors declare no conflict of interest. 


\section{References}

1. Black RE, Morris SS, Bryce J (2003) Where and why are 10 million children dying every year? Lancet 361: 2226-2234.

2. de Onis M, Blössner M, Borghi E, Frongillo EA, Morris R (2004) Estimates of global prevalence of childhood underweight in 1990 and 2015. JAMA 291: 2600-2606.

3. Lahariya C (2008) State of the World's Children 2008. Indian Pediatr 45: 222-223.

4. Agency ZZNS, ICF I (2012) Zimbabwe Demographic and Health Survey 2010-11. Calverton, Maryland: ZIMSTAT and ICF International Inc.

5. Chesire EJ, Orago AS, Oteba LP, Echoka E (2008) Determinants of under nutrition among school age children in a Nairobi peri-urban slum. East Afr Med J 85: 471-479.

6. Zerfu M, Mekasha A (2006) Anthropometric assessment of school age children in Addis Ababa. Ethiop Med J 44: 347-352.

7. Jinabhai CC, Taylor M, Sullivan KR (2003) Implications of the prevalence of stunting, overweight and obesity amongst South African primary school children: a possible nutritional transition? Eur J Clin Nutr 57: 358-365.

8. Jafar TH, Qadri Z, Islam M, Hatcher J, Bhutta ZA, et al. (2008) Rise in childhood obesity with persistently high rates of undernutrition among urban school-aged Indo-Asian children. Arch Dis Child 93: 373-378.

9. Best C, Neufinger N, van Geel L, van den Briel T, Osendarp S (2010) The nutritional status of school-aged children: why should we care? Food Nutr Bull 31: 400-417.

10. Beaton G, Kelly A, Kevany J, Martorell R, Mason J (1990) Appropriate uses of anthropometric indices in children. ACC/SCN state of the art series Nutrition Policy Discussion paper No. 7. Geneva: United Nations Administrative Committee on Nutrition.

11. Martorell R (1999) The nature of child malnutrition and its long-term implications. Food \& Nutrition Bulletin 20: 288-292.

12. Pelletier DL (1994) The relationship between child anthropometry and mortality in developing countries: implications for policy, programs and future research. J Nutr 124: 2047S-2081S.

13. de Onis M, Onyango AW, Borghi E, Siyam A, Nishida C, et al. (2007) Development of a WHO growth reference for school-aged children and adolescents. Bull World Health Organ 85: 660-667.

14. Ejaz MS, Latif N (2010) Stunting and micronutrient deficiencies in malnourished children. J Pak Med Assoc 60: 543-547.

15. Hettiarachchi M, Liyanage C (2012) Coexisting micronutrient deficiencies among Sri Lankan pre-school children: a community-based study. Matern Child Nutr 8: 259-266.

16. Chhagan MK, Van den Broeck J, Luabeya KK, Mpontshane N, Tomkins A, et al. (2010) Effect on longitudinal growth and anemia of zinc or multiple micronutrients added to vitamin A: a randomized controlled trial in children aged 6-24 months. BMC Public Health 10: 145.

17. Jack SJ, Ou K, Chea M, Chhin L, Devenish R, et al. (2012) Effect of micronutrient sprinkles on reducing anemia: a cluster-randomized effectiveness trial. Arch Pediatr Adolesc Med 166: 842-850.

18. Suchdev PS, Ruth LJ, Woodruff BA, Mbakaya C, Mandava U, et al. (2012) Selling Sprinkles micronutrient powder reduces anemia, iron deficiency, and vitamin A deficiency in young children in Western Kenya: a cluster-randomized controlled trial. Am J Clin Nutr 95 1223-1230.

19. Arthur JR, McKenzie RC, Beckett GJ (2003) Selenium in the immune system. J Nutr 133: 1457S-9S.

20. Rayman MP (2000) The importance of selenium to human health. Lancet 356: 233-241.

21. De Silva V, Woznichak MM, Burns KL, Grant KB, May SW (2004) Selenium redox cycling in the protective effects of organoselenides against oxidant-induced DNA damage. J Am Chem Soc 126: 2409-2413.

22. Lewin MH, Arthur JR, Riemersma RA, Nicol F, Walker SW, et al. (2002) Selenium supplementation acting through the induction of thioredoxin reductase and glutathione peroxidase protects the human endothelial cell line EAhy926 from damage by lipid hydroperoxides. Biochim Biophys Acta 1593: 85-92.

23. Beck MA, Esworthy RS, Ho YS, Chu FF (1998) Glutathione peroxidase protects mice from viral-induced myocarditis. FASEB J 12: 1143-1149.

24. Combs GF Jr, Gray WP (1998) Chemopreventive agents: selenium. Pharmacol Ther 79: 179-192.

25. Nève J (1996) Selenium as a risk factor for cardiovascular diseases. J Cardiovasc Risk 3: 42-47.

26. Yu MW, Horng IS, Hsu KH, Chiang YC, Liaw YF, et al. (1999) Plasma selenium levels and risk of hepatocellular carcinoma among men with chronic hepatitis virus infection. Am J Epidemiol 150: 367-374.

27. Baum MK, Shor-Posner G, Lai S, Zhang G, Lai H, et al. (1997) High risk of HIV-related mortality is associated with selenium deficiency. J Acquir Immune Defic Syndr Hum Retrovirol 15: 370-374.

28. Look MP, Rockstroh JK, Rao GS, Kreuzer KA, Spengler U, et al. (1997) Serum selenium versus lymphocyte subsets and markers of disease progression and inflammatory response in human immunodeficiency virus-1 infection. Biol Trace Elem Res 56: 31-41.

29. Kurewa EN, Kandawasvika GQ, Mhlanga F, Munjoma M, Mapingure MP, et al. (2011) Realities and Challenges of a Five Year Follow Up of Mother and Child Pairs on a PMTCT Program in Zimbabwe. Open AIDS J 5: 51-58.

30. CMAM Task Force (2011) Management of acute malnutrition in Zimbabwe A quick reference guide version 1. Ministry of health and child welfare zimbabwe, Harare, Zimbabwe May 2011.

31. Nhien NV, Khan NC, Yabutani T, Ninh NX, Chung le TK, et al. (2008) Relationship of low serum selenium to anemia among primary school children living in rural Vietnam. J Nutr Sci Vitaminol (Tokyo) 54: 454-459.

32. Amare B, Moges B, Fantahun B, Tafess K, Woldeyohannes D, et al. (2012) Micronutrient levels and nutritional status of school children living in Northwest Ethiopia. Nutr J 11: 108.

33. Fordyce FM (2013) Selenium deficiency and toxicity in the environment: Springer ISBN9400743742.

34. Lwambo NJ, Brooker S, Siza JE, Bundy DA, Guyatt H (2000) Age patterns in stunting and anaemia in African schoolchildren: a crosssectional study in Tanzania. Eur J Clin Nutr 54: 36-40.

35. Tang W, Shen X, Mao X, Huang J, Cai W (2013) [Investigation of nutritional status of pupils and dietary survey in primary schools in poor counties of Guangxi and Yunnan]. Wei Sheng Yan Jiu 42: 571-575.

36. Sandjaja S, Budiman B, Harahap H, Ernawati F, Soekatri M, et al. (2013) Food consumption and nutritional and biochemical status of 0.5-12year-old Indonesian children: the SEANUTS study. Br J Nutr 110 Suppl 3: S11-20.

37. Mohd NM, Yeo J, Huang MS, Kamarul AM, Koh MT, et al. (2011) Nutritional status of children living with HIV and receiving antiretroviral (ARV) medication in the Klang Valley, Malaysia. Malays J Nutr 17: 19-30

38. Daboné C, Delisle HF, Receveur O (2011) Poor nutritional status of schoolchildren in urban and peri-urban areas of Ouagadougou (Burkina Faso). Nutr J 10: 34.

39. Lazzeri G, Rossi S, Pammolli A, Pilato V, Pozzi T, et al. (2008) Underweight and overweight among children and adolescents in Tuscany (Italy). Prevalence and short-term trends. J Prev Med Hyg 49: 13-21.

40. Sandjaja, Poh BK, Rojroonwasinkul N, Le Nyugen BK, Budiman B, et al. (2013) Relationship between anthropometric indicators and cognitive performance in Southeast Asian school-aged children. Br J Nutr 110 Suppl 3: S57-64.

41. Albertini A, Tripodi A, Fabbri A, Mattioli M, Cavrini G, et al. (2008) Prevalence of obesity in 6- and 9-year-old children living in CentralNorth Italy. Analysis of determinants and indicators of risk of overweight. Obes Rev 9: 4-10. 
Citation: Kuona P, Mashavave G, Kandawasvika GQ, Dzangare J, Masanganise M, et al. (2014) Serum Selenium Levels and Nutritional Status of School Children from an HIV Prevention Programme in Zimbabwe. J Trop Dis 2: 134. doi:10.4172/2329-891X.1000134

Page 7 of 7

42. Danielzik S, Pust S, Landsberg B, Müller MJ (2005) First lessons from the Kiel Obesity Prevention Study (KOPS). Int J Obes (Lond) 29 Suppl 2 : S78-83.

43. McDonald CM, Olofin I, Flaxman S, Fawzi WW, Spiegelman D, et al. (2013) The effect of multiple anthropometric deficits on child mortality: meta-analysis of individual data in 10 prospective studies from developing countries. Am J Clin Nutr 97: 896-901.

44. Ferrand RA, Luethy R, Bwakura F, Mujuru H, Miller RF, et al. (2007) HIV infection presenting in older children and adolescents: a case series from Harare, Zimbabwe. Clin Infect Dis 44: 874-878.

45. Devi NP, Chandrasekaran K, Bhavani PK, Thiruvalluvan C, Swaminathan S (2011) Persistence of stunting after highly active antiretroviral therapy in HIV-infected children in South India. Indian Pediatr 48: 333-334.

46. Padmapriyadarsini C, Pooranagangadevi N, Chandrasekaran K, Subramanyan S, Thiruvalluvan C, et al. (2009) Prevalence of Underweight, Stunting, and Wasting among Children Infected with Human Immunodeficiency Virus in South India. Int J Pediatr 2009: 837627.

47. Nalwoga A, Maher D, Todd J, Karabarinde A, Biraro S, et al. (2010) Nutritional status of children living in a community with high HIV prevalence in rural Uganda: a cross-sectional population-based survey. Trop Med Int Health 15: 414-422.

48. Seth A, Chandra J, Gupta R, Kumar P, Aggarwal V, et al. (2012) Outcome of HIV exposed infants: experience of a regional pediatric center for HIV in North India. Indian J Pediatr 79: 188-193.

49. Chiabi A, Lebela J, Kobela M, Mbuagbaw L, Obama MT, et al. (2012) The frequency and magnitude of growth failure in a group of HIV-infected children in Cameroon. Pan Afr Med J 11: 15
50. Safaralizadeh R, Sirjani M, Pourpak Z, Kardar G, Teimourian S, et al. (2007) Serum selenium concentration in healthy children living in Tehran. Biofactors 31: 127-131.

51. Khalili H, Soudbakhsh A, Hajiabdolbaghi M, Dashti-Khavidaki S, Poorzare A, et al. (2008) Nutritional status and serum zinc and selenium levels in Iranian HIV infected individuals. BMC Infect Dis 8: 165.

52. Ndagije F, Baribwira C, Coulter JB (2007) Micronutrients and T-cell subsets: a comparison between HIV-infected and uninfected, severely malnourished Rwandan children. Ann Trop Paediatr 27: 269-275.

53. Johnson CC, Fordyce FM, Rayman MP (2010) Symposium on 'Geographical and geological influences on nutrition': Factors controlling the distribution of selenium in the environment and their impact on health and nutrition. Proc Nutr Soc 69: 119-132.

54. Hurst R, Siyame EW, Young SD, Chilimba AD, Joy EJ, et al. (2013) Soiltype influences human selenium status and underlies widespread selenium deficiency risks in Malawi. Sci Rep 3: 1425.

55. Weeks BS, Hanna MS, Cooperstein D (2012) Dietary selenium and selenoprotein function. Med Sci Monit 18: RA127-132.

56. Wang J, Li H, Li Y, Yu J, Yang L, et al. (2013) Speciation, distribution, and bioavailability of soil selenium in the Tibetan Plateau Kashin-beck disease area-a case study in Songpan County, Sichuan Province, China. Biol Trace Elem Res 156: 367-375.

57. Millán Adame E, Florea D, Sáez Pérez L, Molina López J, López-González B, et al. (2012) Deficient selenium status of a healthy adult Spanish population. Nutr Hosp 27: 524-528. 